\title{
Strategi Pemasaran makanan tradisional Tiwul sebagai Destinasi wisata kuliner di Gunung Kidul Jogja
}

\author{
Nadila Ayuning Putri ${ }^{1}$, Erwin Permana ${ }^{2}$, M. Nuruddin Subhan ${ }^{3}$ \\ Fakultas Ekonomi dan bisnis, Universitas Pancasila Jakarta \\ Emial : ${ }^{1}$ nadilaaputri0@gmail.com; ${ }^{2}$ erwin.permana@univ.pancasila.ac.id, \\ ${ }^{3}$ nuruddin.subhan@univpancasila.ac.id
}

\begin{abstract}
Tujuan penelitian ini untuk menganalisis strategi pemasaran bisnis makanan tradisional Tiwul sebagai destinasi wisata kuliner di Gunung Kidul Jogja. Pada penelitian ini penulis menggunakan metode penelitian pendekatan kualitatif deskriptif. Data yang dikumpulkan oleh penulis melalui wawancara secara mendalam dengan responden penelitian. Hasil penelitian yang di lakukan menunjukkan bahwa strategi pemasaran makanan tradisional Tiwul sebagai destinasi wisata kuliner di Daerah Gunung Kidul terdiri dari empat strategi, yaitu strategi produk, strategi harga, strategi kebersihan dan kenyamanan serta strategi promosi. Strategi produk yang digunakan pada Toko Oleh-Oleh Tiwul Kukus yaitu dengan menyediakan produk makanan tradisional yang ada di Daerah Gunung Kidul berkualitas cita rasa yang terjaga. Strategi harga yang digunakan yaitu dengan menerapkan harga yang terjangkau bagi masyarakat pada umumnya. Strategi kebersihan dan kenyamanan yang diterapkan yaitu menerapkan kebersihan pada area produksi dan kualitas makanan serta kenyamanan fasilitas toko. Karena dengan adanya kebersihan, pelanggan tidak akan khawatir lagi dalam menikmati produk yang ditawarkan. Strategi promosi yang digunakan pada Toko Oleh-Oleh Tiwul Kukus yaitu dengan cara pemasaran di semua media baik online maupun offline. Pemasaran online dilakukan dengan memanfaatkan media social sedangkan offline dilakukan dengan "jemput bola" yakni penjemputan bis ke lokasi destinasi wisata agar wisatawan tertarik untuk membeli.
\end{abstract}

Kata Kunci: Strategi pemasaran; kuliner tiwul.

Abatrac: The purpose of this study is to analyze the marketing strategy of the Tiwul traditional food business as a culinary tourism destination in Gunung Kidul Jogja. In this study, the authors used a descriptive qualitative approach. Data collected by the authors through in-depth interviews with research respondents. The results of the research conducted indicate that the marketing strategy of Tiwul traditional food as a culinary tourism destination in the Gunung Kidul Region consists of four strategies, namely product strategy, price strategy, cleanliness and comfort strategy, and promotion strategy. The product strategy used at the Tiwul Kukus Souvenir Shop is to provide traditional food products in the Gunung Kidul area with maintained quality and taste. The pricing strategy used is to apply affordable prices for the general public. The hygiene and comfort strategy applied is to apply cleanliness in the production area and the quality of food and shop facilities. Because with cleanliness, customers will no longer worry about enjoying the products offered. The promotional strategy used at the Tiwul Kukus Souvenir Shop is using marketing in all media, both online and offline. Online marketing is done by utilizing social media while offline is done by "picking up the ball", namely picking up tourist destinations so that tourists are interested in buying.

Keywords: Marketing Strategy ; tiwul culinary 


\section{A. PENDAHULUAN}

Peluang bisnis makanan tradisional di Indonesia termasuk dalam kategori yang sangat menguntungkan, dimana peminatnya sangat banyak dan mudah di dapatkan. Banyak masyarakat yang memilih untuk berbisnis dengan makanan tradisional karena produksi atau pembuatannya yang relatif lebih mudah, di antaranya menjual produk mereka hanya dengan sekala kecil. Begitupun cara pemasarannya, karena umumnya bisnis makanan tradisional hanya di geluti oleh masyarakat yang lanjut usia, atau tua.

Gunung Kidul adalah satu dari empat kabupaten yang terdapat di Daerah Istimewa Yogyakarta, memiliki luas yang paling besar yaitu satu per tiga dari luas daerah induknya, namun menempati tingkatan paling rendah kependudukannya di bandingkan dengan kabupaten lainnya (wikipedia), memiliki banyak ke indahan alam di dalamnya, gunung kidul kini telah menjadi salah satu daerah dengan wisatawan terbesar di indonesia setiap tahunnya. Terdaftar 55 destinasi wisata di catatan pemerintah, dan masih banyak lagi. memiliki target pengunjung 147.067 orang dengan pendapatan sekitar Rp 1,1 miliar (Kompas, 2021) kini Gunung Kidul menjadi salah satu pilihan destinasi wisata dambaan untuk para wisatawan lokal dari penjuru negri untuk menghabiskan waktu liburannya.

Kabupaten Gunung Kidul adalah wilayah yang beriklim tropis, dengan catatan topografi yang di dominasi dengan daerah kawasan perbukitan krats, dimana di dalamnya memiliki goa-goa alam yang menaubkan dan juga sungai bawah tanah yang mengalir deras. Melihat kondisi tersebut membuat lahan di kawasan selatan yang di nilai kurang subur dan berakibat kepada budidaya petanian yang ada di kawasan tersebut kurang baik atau optimal. Karena keadaan geografis tersebug maka salah satu tumbuhan yang banyak di jumpai di Daerah Gunung Kidul salah satunya adalah singkong.

Dalam catatannya, salah satu penyumbang bahan pangan terbesar di Daerah Istimewa Yogyakarta, adalah Gunung Kidul terutama umbi umbi an yaitu ubi kayu. Ubi kayu yang di gunakan masyarakat sebagai salah satu bahan pangan pengganti beras sangat penting untuk menyukseskan keberhasilan diversifikasi pangan di daerah Gunung Kidul. Gunung kidul memiliki potensi singkong yang sangat besar sehingga termasuk dalam salah satu daerah dengan petani singkong terbesar (acara.co.id, 2020).

Tabel 1. Luas Panen, Produksi, dan Produktivitas Ubi Kayu

\begin{tabular}{|l|l|l|l|}
\hline Provinsi & $\begin{array}{l}\text { Luas Panen } \\
\text { (ha) }\end{array}$ & Produksi (ton) & $\begin{array}{l}\text { Produktivitas } \\
\text { (ton/ha) }\end{array}$ \\
\hline Lampung & 212.100 & 5.541 .692 & 26,13 \\
\hline $\begin{array}{l}\text { Jawa } \\
\text { Tengah }\end{array}$ & 126.237 & 3.243 .835 & 25,7 \\
\hline Jawa Timur & 115.134 & 2.901 .987 & 25,21 \\
\hline Jawa Barat & 74.643 & 1.901 .216 & 25,47 \\
\hline $\begin{array}{l}\text { Nusa } \\
\text { Tenggara } \\
\text { Timur }\end{array}$ & 58.748 & 701.892 & 11,95 \\
\hline $\begin{array}{l}\text { DI } \\
\text { Yogyakarta }\end{array}$ & 54.355 & 1.028 .408 & 18,92 \\
\hline $\begin{array}{l}\text { Sumatera } \\
\text { Utara }\end{array}$ & 28.996 & 1.001 .877 & 34,55 \\
\hline
\end{tabular}


ISSN NO. (PRINT) 2598-0823, (ONLINE) 2598-2893

\begin{tabular}{|l|l|l|l|}
\hline Provinsi & $\begin{array}{l}\text { Luas Panen } \\
\text { (ha) }\end{array}$ & Produksi (ton) & $\begin{array}{l}\text { Produktivitas } \\
\text { (ton/ha) }\end{array}$ \\
\hline $\begin{array}{l}\text { Sumatera } \\
\text { Selatan }\end{array}$ & 14.210 & 519.328 & 36,55 \\
\hline $\begin{array}{l}\text { Sulawesi } \\
\text { Selatan }\end{array}$ & 13.397 & 309.554 & 23,11 \\
\hline $\begin{array}{l}\text { Sulawesi } \\
\text { Tenggara }\end{array}$ & 9.588 & 223.354 & 23,3 \\
\hline
\end{tabular}

(Sumber : inaagrimap.litbang.pertanian.go.id, 2016).

Tabel 1 menunjukkan bahwa DI Yogyakarta termasuk 10 besar daerah pertanian singkong terbesar di Indonesia (Sedangkan untuk lokasi kawasan pertanian nasional, Daerah Gunung Kidul juga tercatat sebagai Lokasi Kawasan Pertanian penghasil komoditas ubi kayu, di DI Yogyakarta.

\begin{tabular}{|c|c|c|c|c|c|}
\hline Provinsi & Kawasan & Kabupaten & Provinsi & Kawasan & Kabupaten \\
\hline \multirow{3}{*}{$\begin{array}{l}\text { Sumatera } \\
\text { Utara }\end{array}$} & \multirow{2}{*}{1} & Deli Serdang & \multirow{4}{*}{ Jawa Tengah } & 1 & Banjarnegara \\
\hline & & Serdang Bedagai & & 2 & Wonogiri \\
\hline & 2 & Simalungun & & \multirow{2}{*}{3} & Pati \\
\hline \multirow{6}{*}{ Lampung } & \multirow[b]{2}{*}{1} & Lampung Timur & & & Jepara \\
\hline & & Lampung Tengah & $\begin{array}{l}\text { DI } \\
\text { Yogyakarta }\end{array}$ & 1 & $\begin{array}{l}\text { Gunung } \\
\text { Kidul }\end{array}$ \\
\hline & \multirow{2}{*}{2} & Lampung Utara & \multirow{3}{*}{ Jawa Timur } & 1 & Pacitan \\
\hline & & Way Kanan & & \multirow[b]{2}{*}{2} & Ponorogo \\
\hline & \multirow[b]{2}{*}{3} & Tulang Bawang & & & Terenggalek \\
\hline & & $\begin{array}{l}\text { Tulang Bawang } \\
\text { Barat }\end{array}$ & \multirow{2}{*}{$\begin{array}{l}\text { Sulawesi } \\
\text { Selatan }\end{array}$} & \multirow[t]{2}{*}{1} & Gowa \\
\hline \multirow{4}{*}{$\begin{array}{l}\text { Jawa } \\
\text { Barat }\end{array}$} & 1 & Sukabumi & & & Jeneponto \\
\hline & \multirow{2}{*}{2} & Garut & & & \\
\hline & & Tasikmalaya & & & \\
\hline & 3 & Sumedang & & & \\
\hline
\end{tabular}

(Sumber : inaagrimap.litbang.pertanian.go.id, 2018).

Tiwul merupakan salah satu Makanan tradisional di Kabupaten Gunung Kidul yang berbahan dasar Singkong. Karena keadaan geografis membuah tanah cenderung lebih kering dan sangat cocok di tanami umi kayu salah satunya singkong. Thiwul adalah makanan khas daerah Gunung Kidul yang sudah ada dan di konsumsi masyarakat sejak zaman dahulu, mula nya Tiwul adalah olahan singkong yang di jadikan makanan pengganti nasi, karena harganya yang relatif murah, mudah di dapatkan, dan bahkan dapat produksi sendiri. Pada zaman dahulu gunung kidul termasuk kedalam salah satu daerah paling terbelakang di indonesia karena keadaan dan letak geografisnya yang susah untuk di kembangkan, masyarakat yang sebagian besar berprofesi sebagai petani dan berekonomi rendah pada saat itu membuat singkong menjadi makanan utama pengganti nasi dengan mengubahnya menjadi "gaplek" terlebih dahulu.

Gaplek itu sendiri adalah salah bahan utama untuk membuat thiwul dan menjadi salah satu bahan maknanan yang berasal dari umbi singkong seperti olahan gathot,dan lainnya. cara pembuatannya yaitu dengan mengupas bersih singkong lalu di keringkan dengan cara menebar di lahan atau tempat yang terkena sinar matahari langsung hingga kering dan Jurnal Pemasaran Kompetitif, Vol. 04, No. 3 / Juni 2021 
nantinya mengeras (Wikipedia). Setelah kering dapat di tumbuk kasar dan di jadi kan nasi Tiwul, namun pada zaman sekarang gaplek telah berinovasi dengan di menjadikan nya tepung sehingga dapat di gunakan untuk bahan kue apapun, namun karena perbedaan kandungan dan tekstur, tepung gaplek sangat berbeda dengan tepung lainnya sehingga penggunaannya pun lebih terbatas.

Semakin berkembangnya dunia kuliner membuat Tiwul juga semakin berinovasi, setelah di jadikan sebagai salah satu makanan utama pengganti nasi, gaplek akhirnya di produksi atau di buat dengan cara yang berbeda dan menjadikannya makanan manis seperti kue kue an pada zaman dahulu oleh masyarakat lokal nya. Tepung gaplek yang telah di tumbuk di olah dengan air dan gula lalu di kukus menggunakan cetakan selama beberapa menit, Setelah selesai Tiwul yang cantik akan di sajikan dengan kukusan kelapa parut di atasnya. Karena pembuatannya yang sederhana, namun menghasilkan rasa yang di luar biasa membuat Tiwul menarik wisatawan yang datang ke daerah Gunung kidul untuk turut mencoba makanan khas daerah tersebut. Dan pada akhirnya makanan rumahan ini beralih menjadi salah satu produk yang di jual bagi beberapa pembisnis di Gunung Kidul.

Beberapa produk Tiwul yang di jual sudah berinovasi dengan racikan - racikan nya masing - masing. Melihat dari salah satu produk Tiwul yang terkenal di gunung kidul, peminat thwiul saat ini sangatlah banyak, makanan khas daerah yang berinovasi ini membuat daya tarik para milenial dan masyarakat luar daerah untuk mencobanya.

Tiwul saat ini dapat di kategorikan sebagai makanan oleh - oleh khas gunung kidul (negerikuindonesia.com). penjualannya lebih besar di ambil oleh wisatawan - wisatawan luar daerah dan membuat peminatnya juga meluas tersebar seluruh daerah di indonesia. Kini nama Tiwul semangkin meroket dan tidak asing lagi, branding yang di lakukan para pembisnis tiwul membuat namanya semakin melejit dan menjadi salah satu destinasi di gunung kidul untuk kulineran.

Harganya pasarannya yang murah juga menjadi alasan daya tarik wisatawan yang datang ke gunung kidul, inovasi yang di lakukan pembisnis juga membuat tiwul tidak lagi sebagai makanan terbelakang. Saat ini tiwul di produksi dengan berbagai macam varian, mulai dari gula jawa, pandan, coklat, bahkan keju yang menjadi daya tarik milenial. Semakin berkembang cara inovasi semakin menarik pula nama tiwul di mata para wisatawan.

Maka untuk menjawab kebutuhan para pelaku bisnis makanan tradisional Tiwul terhadap semakin meningkatnya permintaan Tiwul, maka dibutuhkan strategi pemasaran bisnis yang baik. Penelitian ini bertujuan untuk menganalisis strategi bisnis makanan tradisional Tiwul sebagai destinasi wisata kuliner di Gunung Kidul Yogyakarta.

\section{B. KAJIAN LITERATUR}

\section{Strategi pemasaran}

Strategi merupakan sebuah gagasan yang di lakukan seseorang atau perusahaan yang berkaitan dengan pelaksanaan, perencaan dan eksekusi untuk sebuah aktivitas dalam waktu dan kegiatan tertentu. Di dalam sebuah strategi yang baik akan terdapat beberapa hal seperti koordinasi tim kerja, memiliki tema, mengidentifikasi faktor pendukung yang sesuai dengan prinsip-prinsip pelaksanaan gagasan secara rasional, dan efisien sehingga strategi yang ingin di lakukan memiliki perencanaan untuk mencapai tujuan yang efektif. Menurut salah satu ahli yaitu Tjiptono(2002) definisi Pemasaran adalah suatu proses sosial dan manajerial dimana individu atau kelompok mendapatkan apa yang mereka butuhkan melalui penciptaan, penawaran, dan pertukaran segala sesuatu yang bernilai dengan orang atau kelompok lainnya. 
Strategi pemasaran adalah sebuah upaya yang di lakukan seseorang atau sebuah perusahaan untuk memasarkan dan mengenalkan suatu produk maupun jasa kepada masyarakat, yang di lakukan agar target penjualan dalam sebuah perusahaan dapat tercapai. Menurut Kurtz (2008), strategi pemasaran adalah keseluruhan program perusahaan dalam menentukan target pasar. Kurtz mengatakan bahwa strategi ini bertujuan memuaskan konsumen dengan cara membangun kombinasi dari campuran pemasaran. Campuran yang dimaksud terdiri dari produk, distribusi, promosi, serta harga. strategi pemasaran adalah sebagai jarring untuk penghubung antara bisnis dengan konsumen. Ada empat strategi pemasaran yang dapat di terapkan dalam perusahaan, yaitu: strategi produk, strategi kebersihan, strategi harga, dan strategi promosi.

Bauran pemasaran atau marketing mix adalah suatu istilah yang biasanya digunakan dalam dunia bisnis. Secara harfiah marketing mix ini di tujukan kepada seorang eksekutif bisnis yang biasanya bertugas sebagai peracik bahan-bahan. Dalam hal ini yang berhubungan dengan pemasaran bisnis.

Marketing mix dapat diartikan sebagai strategi kombinasi yang dilakukan oleh bidang pemasaran di dalam sebuah perusahaan. Semua perusahaan menggunakan strategi marketing mix untuk mencapai target penjuakan dan tujuan pemasarannya. Strategi ini juga sangat berguna untuk perusahaan yang menerapkannya untuk menghadapi situasi dimana persaingan akan semakin ketat.

Terdapat 7 Konsep marketing mix yang biasa di katakan dengan konsep 7P. yaitu (Accurate,2020) :

1. Product (Produk)

Produk merupakan sesuatu hal yang dijual dalam sebuah bisnis atau perusahaan. Biasanya terdiri atas barang maupun jasa yang di nilai memiliki kegunaan serta barang dan jasa yang sedang dibutuhkan dan marak di cari oleh konsumen. Salah satu faktor keberhasilan pemasaran produk adalah barang dan jasa yang di jual harus menjawab kebutuhan konsumen.

Namun tidak menutup kemungkinan bahwa suatu barang dan jasa yang akan di pasarkan dan di jual tentunya dituntut memiliki nilai lebih dibanding produk lainnya. Hal itu di sebabkan oleh strategi pemasaran agar produk yang di pasarkan dapat lebih menarik dan menjadi pilihan konsumen. Agar dapat menghadapi kondisi persaingan penjualan yang sangat ketat. banyak produk di pasaran yang serupa dan sejenis namun sengaja di jual ke pasar dalam waktu yang bersamaan.

2. Price (Harga)

Harga adalah sejumlah uang yang harus dikeluarkan oleh seorang konsumen untuk mendapatkan produk yang di inginkan. Harga termasuk kedalam aspek yang penting dalam sebuah penjualan dan pemasaran. Maka untuk mentukannya perlu di lakukan pertimbangan yang matang.

Harga yang sudah tepat biasanya di anggap oleh konsumen ketika harga tersebut bisa di terima oleh konsumen dan perusahaan tetap mendapatkan keuntungan yang sesuai dengan keinginan. 


\section{Place (Tempat)}

Tempat adalah suatu lokasi yang di gunakan perusahaan untuk melakukan proses jual beli produk. Konsep pemasarah ini sangat penting terutama bagi para pelaku usaha konvensional. Perusahaan dan pelaku usaha dengan bisnis konvensional harus mengetahui di mana lokasi strategis yang akan di gunakan untuk melakukan proses penjualan.

Lokasi strategis yang di maksud adalah mudah di temukan dan dikunjungi oleh konsumen. Bila perusahaan atau bisnis modern atau bisnis online biasanya tidak perlu memerlukan lokasi yang strategis karena kekuatan produk yang telah besar dan terkenal tidak memperhatikan lokasi penjualan. Oleh karena itu pengertian aspek tempat lokasi lebih banyak ragamnya. Dapat disesuaikan dengan media yang digunakan dalam penjualan.

4. Process (Proses)

Proses adalah sebuah gabungan dari keseluruhan aktivitas dalam pemasaran dan penjualan. Terdiri dari beberapa hal yaitu prosedur, pelaksanaan pekerjaan, aktivitas, mekanisme, serta hal-hal lainnya. Seluruh aktivitas yang di lakukan berhubungan dengan produk yang dihasilkan serta penjualan dan pemasarannya kepada konsumen

Dalam pelaksanaan aspek proses maka akan terdapat beberapa aktifitas yang berhungan langsung dengan konsumen seperti aktivitas pelayanan dan proses transaksi. Perusahaan memiliki tanggung jawab untuk memberikan pelayanan terbaik untuk kepuasan para konsumennya.

\section{Promotion (Promosi)}

Promosi bertujuan untuk para konsumen agar dapat lebih mengenal dan serta merasa tertarik dengan produk yang di jual sehingga akhirnya akan melakukan pembelian produk. Perusahaan di sarankan memiliki pengetahuan untuk mampu mengubah persepsi dan pandangan konsumen menjadi sebuah pandangan positif terhadap produk yang dijual.

Pada zaman sekarang banyak cara yang dapat di lakukan untuk aktifitas promosi, dapat di lakukan dengan cara face to face yang biasanya sering di lakukan oleh pelaku usaha atau dengan door to door untuk menjemput bola, hingga pada saat ini biasanya penguasa juga melakukan promosi melalui media sosial secara online, seperti aplikasi instagram, youtube, dan pilihan aplikasi lainnya.

\section{People (Orang)}

Orang Yang dimaksud dalam konsep pemasaran ini bukan hanya sebatas konsumen saja. Namun semua SDM yang terlibat, seperti karyawan atau pekerja hingga team manajemen. Aspek ini sangat penting untuk diperhatikan oleh perusahaan. Dikarenakan untuk menyatukan sebuah pemikiran setiap orang bukan lah hal yang mudah dan setiap orang pastinya memiliki kecenderungan yang berbeda beda dalam menjalankan sebuah pekerjaan dan bisnis.

Salah satu bagian SDM yang di nilai paling mempengaruhi adalah yang bertugas untuk melayani secara langsung para konsumen, dimana sikapnya dapat mempengaruhi pemikiran dan persepsi para konsumen, sehingga mudah terjadi salah persepsi dan menimbulkan masalah. Maka perusahaan harus lebih bijak dan memperhatikan kesiapan SDM yang akan di tugaskan. 


\section{Physical Evidence (Bukti Fisik)}

Bukti fisik adalah semua perangkat yang harus digunakan sebagai pendukung dalam sebuah bisnis. Sebuah perangkat penting adanya untuk di miliki sebuah perusahaan, apa lagi untuk sebuah bisnis skala besar, sudah pasti banyak membutuhkan perangkat. Dan akan semakin kompleks dan meluas pula fungsi serta penggunaannya.

\section{Makanan tradisional}

Makanan tradisional adalah makanan dan hidangan yang diwariskan secara turun-temurun atau telah dikonsumsi secara turun-temurun. Makanan tradisional adalah makanan yang biasa dikonsumsi oleh masyarakat tertentu, dengan cita rasa khas yang diterima oleh masyrakat tertentu.

Makanan tradisional adalah makanan yang dipengaruhi oleh kebiasaan makan yang ada di dalam masyarakat di suatu daerah dan menyatu pada sistem sosial budaya di daerahdaerah Indonesia di berbagai golongan etnik di dalamnya. Makanan tersebut di konsumsi dan di sukai oleh masyarakat, karena cita rasa, tekstur dan aroma nya sesuai dengan selera masyarakayat di daerah tersebut. Dan juga umumnya makan khas daerah tidak mudah berubah dari cita rasa dan keunikannya.

Thiwul adalah salah satu makanan tradisional yang asalnya dari Daerah Gunung Kidul, Yogyakarta. Berbahan baku singkong thiwul biasa di jadikan makanan pengganti nasi oleh masyarakat, thiwul terbuat dari $90 \%$ tepung gaplek, yaitu sebuah singkong yang telah di kupas dan di keringkan di bawah sinar matahari dan di tumbuk halus hingga bertekstur seperti tepung pada umumnya, rasanya lebih condong seperti singkong yang manis, dan biasanya berwarna kecoklatan. Nasi thiwul adalah awal mula olahan thiwul yang original dengan cita rasa yang lezat dan di masak dengan cara di kukus dan di sajikan bersama lauk pauk untuk konsumsi hari-hari. Sedangkan thiwul yang manis adalah olahan inovasi thiwul yang di padukan dengan berbagai macam rasa dan varian seperti rasa gula jawa, pandan, stoberi, coklat, bahkan keju. Biasanya thiwul manis di sajikan sebagai hidangan penutup atau kue, penyajiannya di taburi dengan kelapa parut yang telah di kukus atau karamel di atasnya.

\section{Review Penelitian terdahulu}

Wijaya, 2013. dalam penelitian berjudul "Analisis Strategi Pemasaran Makanan Khas Tradisional (Studi Kasus Pada Home Industry Rengginang Halimatus Sa'diyah Kalibaru di Kabupaten Banyuwangi). Dari penelitian yang di lakukan penulis pada Home Industry Halimatus Sa'diyah di pahami bahwa strategi pemasaran yang di lakukan dengan dua cara yaitu, cara pemasaran langsung dan tidak langsung. Pemasaran secara langsung yang di maksud adalah konsumen dapat datang langsung ke lokasi untuk mendapatkan produk rengginang atau dengan memesan melalui media telefon, dan pemasaran tidak langsung adalah membeli produk melalui toko-toko seperti minimarket yang berkerja sama di daerah Kalibiru. Memiliki kelebihan perusahaan yaitu produk yang di jual adalah produk berkualitas, dan kelemahannya yaitu tidak memiliki modal yang banyak sehingga mempengaruhi produksi.

Yumanda, 2009. dalam penelitian yang berjudul "Strategi Pemasaran Kripik Singkong Industri Rumah Tangga Cap Kelinci di Tanjung Morawa Kabupaten Deli Serdang". Dari penelitian yang di lakukan oleh penulis, dapat di pahami bahwa strategi yang di ambil oleh Industri Rumah Tangga Cap Kelinci adalah salah satu strategi bisnis yaitu keunggulan produk. Ada beberapa kelebihan dari penjualan produk ini, dimana produk berpeluang tinggi untuk masuk dan bersaing di pasar monopolistik, namun keuangannya seperti kas perusahaan tidak mereka miliki, dan kurangnya aktifitas promosi yang di lakukan di semua 
media. Sedangkan banyak ancaman yang akan hadir bila hal tersebut tidak segera di perbaiki, melihat daya beli konsumen yang mungkin tidak selalu stabil.

Burhanuddin, 2019.dalam penelitiann yang berjudul "Strategi Pemasaran Makanan Khas Tradisional di Kecamatan Wotu". Dari penelitian yang di lakukan dapat di pahami bahwa strategi pengembangan bisnis yang di lakukan oleh Rumah Makan Satria hanya dengan melayani konsumen yang langsung datang ke lokasi, memperhatikan daya tahan produknya maka rumah makan Satria juga dapat melayani pembelian melalui via telepon ke area-area tertentu saja. Pemilik berharap dengan adanya pengembangan bisnis yang lebih baik akan membuat rumah makan Satria dapat berkembang ke daerah lainnya atau dengan berkerja sama dengan orang lain agar makanan khas tradisional ini dapat terus di lestarikan

Dari berbagai penelitian tentang bisnis makanan tradisional, terdapat beberapa persamaan mengenai cara pemasarannya Wijaya, 2013 : Yumanda, 2009 : Burhanuddin, 201. Pemasaran dalam sebuah bisnis adalah salah satu hal terpenting dan hampir seluruhnya mengutamakan kualitas dan menjaga hungungan dengan konsumennya sehingga tercipta hubungan yang baik antara produsen dan konsumen. Sedangkan perbedaan penelitian ini dengan penelitian terdahulu adalah lokasi dan produk makanan yang akan di pasarkan. Penelitian ini menganalisis strategi pemasaran makanan khas daerah yang berasal dari Daerah Gunung Kidul, Yogyakarta.

Walaupun ada banyak penelitian yang telah di lakukan oleh orang lain dan membahas tentang hal yang sama, yaitu strategi pemasaran makanan tradisional. Namun penelitian tersebut memiliki fokus topik masing-masing, beberapa diantaranya membahas tentang tanggapan konsumen, sedangkan penelitian ini di lakukan penulis untuk fokus terhadap strategi pemasaran di pusat toko oleh-oleh thiwul kukus. Sehingga peneliti dapat mengkaji dan mengetahui bagaimana strategi pemasaran yang baik dan tepat, dan masyarakat atau konsumen memiliki ketertarikan untuk mengkonsumsi dan menjadikan makanan khas daerah ini sebagai salah satu destinasi kuliner yang di incar di Daerah Gunung Kidul, Yogyakarta. Itulah yang membedakan penelitian ini dengan penelitian lainnya.

\section{B. METODOLOGI PENELITIAN}

Penulis menggunakan jenis penelitian kualitatif deskiptif dalam penelitian kali ini. Penelitian kualitatif yang di maksud adalah suatu data yang mana tidak di paparkan berupa angka, atau proses keadaan dan kegiatan yang di ungkapkan dan di jelaskan pada suatu masalah serta keadaan(kemenkeu,2019). Jenis yang di gunakan dalam penelitian kali ini adalah penelitian deskriptif, metode ini di lakukan dengan cara meneliti sebuah objek, sekelompok manusia, suatu sistem pemikiran, kondisi, bahkan suatu peristiwa yang ada dengan membuat suatu gambaran secara sistemanis atau deskripsi, datanya faktuan dan akurat mengenai sifat-sifat atau fakta-fakta serta berhubungan antara fenomena yang di selidiki dengan interpretasi yang tepat (Nazir, 2005).

Data penelitian menggunakan data primer dan data sekunder. Data primer berasal dari dari pelaku usaha Tiwul yang dilakukan dengan wawancara langsung. Sedangkan data sekunder adalah data yang di peroleh dari berbagai sumber-sumber baik yang sudah diolah maupun belum di olah yang menunjang dan berguna bagi penelitian seperti profil tempat penelitian dan teori-teori dari berbagai literature yang digunakan sebagai landasan argument teoritis. Teknik pengumpulan data yang di lakukan penulis adalah wawancara dan studi dokumen, kedua teknik pengumpulan data tersebut dapat di jelaskan sebagai berikut (sumber:ciputrauceo.net) :

a) Wawancara. Teknik pengumpulan data melalui wawancara dilakukan dengan cara tatap muka dan tanya jawab langsung kepada narasumber. Seiring dengan 
perkembangan teknologi di Indnesia serta adanya situasi pandemic maka teknik pengumpulan data dengan cara wawancara yang dilakukan melalui media-media digital

b) Studi dokumen.teknik pengumpulan data melalui Studi dokumen adalah jenis pengumpulan data dengan melakukan penelitian berbagai macam dokumen yang berguna untuk bahan analisis seperti contohnya dokumentasi tentang demografi, profile usaha, dan kondisi sosial ekonomi masyarakat.

Objek penelitian ini secara khusus dilakukan di Toko Oleh-Oleh Tiwul Kukus. Penulis memilih Toko Oleh-Oleh Tiwul kukus untuk melakukan riset karena menjadi pelopor Produsen Tiwul yang terbesar dan selalu berinovasi sehingga di minati banyak kalangan dan menjadi percontohan untuk UMKM di Daerah Gunung Kidul, Yogyakarta. Inovasinya menjadi gebrakan baru di dunia kuliner tradsional Daerah Gunung Kidul sehingga di lirik langsung oleh pemerintah dan jajarannya karena menjadi salah satu alasan wisatawan datang ke Daerah Gunung Kidul.

\section{HASIL DAN PEMBAHASAN}

Strategi pemasaran dalam bisnis makanan tradisional harus memiliki aspek yang membuat produk berbeda dan menarik para konsumen untuk membeli karena karakteristiknya yang tidak bisa bertahan lama, serta memiliki jangka waktu expired. Sehingga target penjualan harus sangat di perhatikan dan terukur. Sehingga Inovasi dan strategi pemasaran sangat di butuhkan dalam bisnis makanan tradisional khas daerah. Karena hal itu pemasar atau marketing dituntut oleh perusahaan untuk dapat mencapai seluruh target dan kinerja pemasaran yang maksimal dengan sumber daya yang tersedia. Kinerja pemasaran dapat dilihat dari beberapa hal seperti yang kuat, memiliki pangsa pasar yang besar, penjualan yang tinggi, pelayanan yang baik, profit yang di dapatkan, loyalitas karyawan dan perusahaan, dan lain-lain. Hal tersebut harus pemasar capai dengan dana promosi yang tersedia,

Sistem pemasaran yang di lakukan oleh-Toko Oleh-Oleh Thiwul Kukus memang masih terbilang sederhana. Namun sudah banyak hal yang di lakukan untuk pemasaran produk, misalnya dengan melakukan pemasaran melalui media sosial seperti Facebook, Instagram, dan Web Google, agar lebih mudah di jangkau oleh konsumen dan memberikan layanan yang terbaik. Toko Oleh-Oleh Tiwul Kukus adalah salah satu tempat produksi makanan Khas Daerah Gunung Kidul yaitu Tiwul yang dapat memproduksi Tiwul lebih dari 1.000 dalam sebulan (Catatan penjualan perusahaan, 2021)

Toko Oleh-Oleh Thiwul kukus menjadi pelopor Produsen Tiwul yang terbesar dan selalu berinovasi sehingga di minati banyak kalangan, selalu berinovasi dalam pemasaran membuat produk Tiwul Kukus menjadi percontohan untuk UMKM di Daerah Gunung Kidul, Yogyakarta. Inovasinya menjadi gebrakan baru di dunia kuliner tradisonal Daerah Gunung Kidul sehingga di lirik langsung oleh pemerintah dan jajarannya karena menjadi salah satu alasan wisatawan datang ke Daerah Gunung Kidul. Contoh inovasi yang di lakukan adalah mengubah cara produksi Thiwul, mengubah bentuk tampilan Thiwul, dan juga memperkaya varian rasa yang di jual. Seperti : coklat, keju, pandan, stroberi, gula jawa, dan gula pasir. 


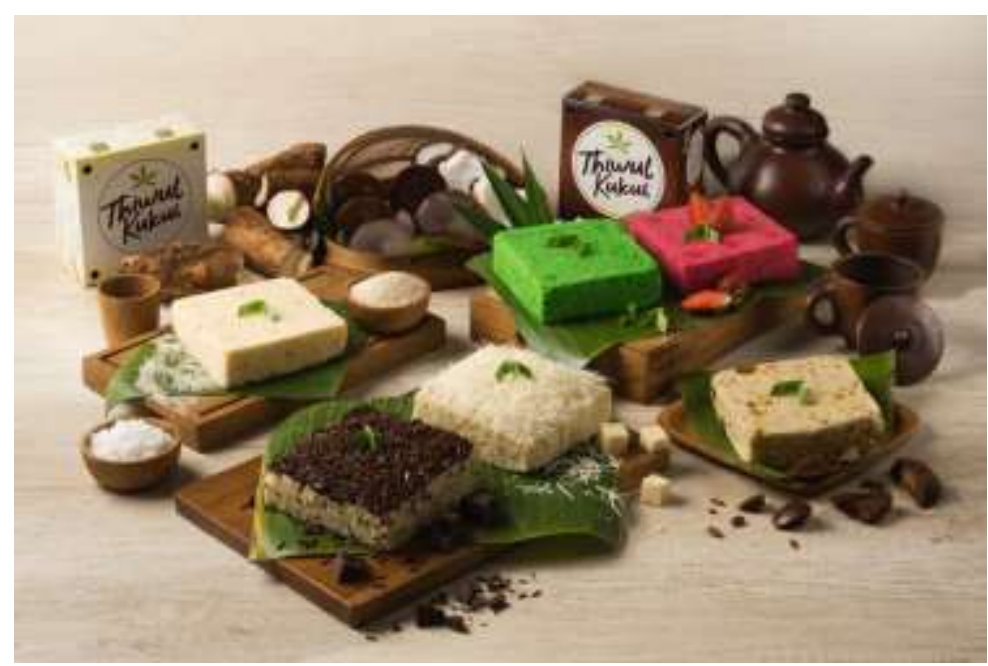

Gambar 1. Produk Thiwul Toko Oleh-Oleh Tiwul Kukus (Sumber: dokumentasi perusahaan)

Sampai saat ini Tiwul Kukus hanya memiliki 2 gerai, Pusat nya di Daerah Gunung Kidul dan cabang pertamanya di daerah Sleman, Yogyakarta. Tapi tidak menutup kemungkinan untuk terus melebarkan sayapnya di daerah daerah Yogyakarta agar semakin di kenal dan menjadi icon untuk mengingat Daerah Gunung Kidul dan meningkatkan wisatawan untuk berkunjung. Tedjo selaku pemilik Toko Oleh-Oleh Tiwul Kukus, dalam suatu wawancara menjelaskan "Kami selalu berusaha dan mengemas produk makanan khas tradisional Tiwul agar semenarik mungkin mengacu pada inovasi di brand brand besar sehingga memiliki daya tarik wisatawan di berbagai kalangan".

Pemilik juga menjelaskan bahwa Tiwul Kukus memiliki dua cara pemasaran untuk mendatangkan konsumen. Pertama, pemasaran lewat media sosial, membagikan brosur dan memasang plang atau spanduk produk di beberapa titik daerah. Kedua, teknik pemasaran yang sudah dikenal lama dan unik di destinasi wisata Gunung Kidul adalah cara pemasaran "jemput bola". Jemput bola merupakan istilah menjemput bis para wistawan di lokasi destinasi wisata di Daerah Gunung Kidul seperti contohnya: Pantai, Goa pindul, dan wisata lainnya. Cara tersebut di lakukan karena daya tarik terbesar di Daerah Gunung Kidul adalah Destinasi wisatanya, dan produk Tiwul adalah makanan khas daerah yang peminatnya wisatawan yang tertarik dan penasaran dengan adanya makanan yang belum lumrah terdengar atau masih jarang ada.

Pemilik mengatakan bahwa harga produk Tiwul miliknya memang terbilang sedikit lebih mahal dari pada pasarannya, hal itu di sebabkan karena bahan baku, cara produksi, dan penyajiannya yang berbeda dengan produk Tiwul lainnya. Toko Oleh-Oleh Tiwul Kukus memproduksi Tiwul dengan cara di kukus menggunakan teknologi canggih yaitu mesin steamer, berbeda dengan produk lainnya yang masih menggunakan kompor. Tiwul kukus juga memiliki bentuk yang berbeda, dan pengemasannya menggunakan kardus premium. Adapun harga yang di tetapkan adalah Rp.18.000 untuk 1 kotak Tiwul semua varian, sedangkan Produk Tiwul lainnya di jual dengan harga pasarannya mulai dari harga Rp.10.000 sampai Rp. 15.000 untuk varian yang lebih unik seperti keju dan coklat. 


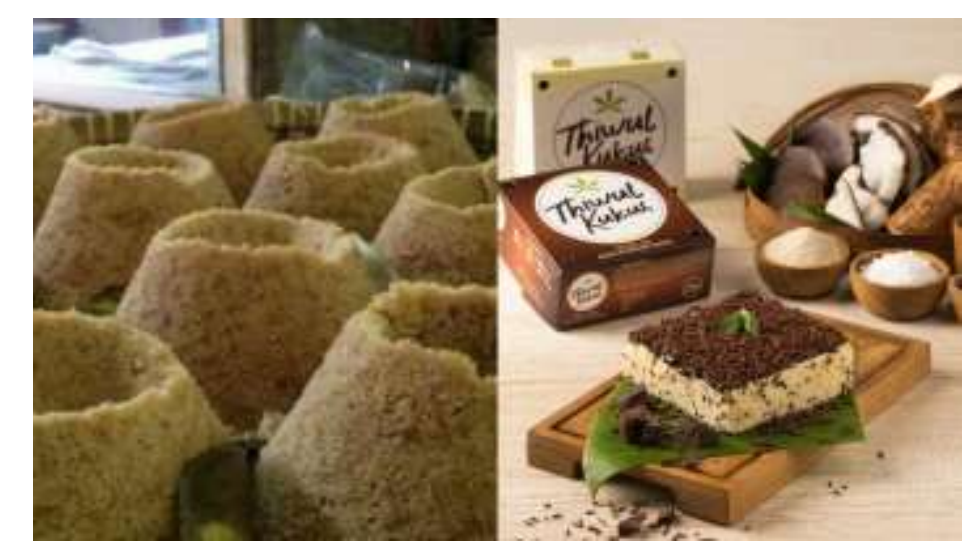

Gambar 2. Perbandingkan penyajian Poduk Tiwul lain dengan Produk Tiwul Kukus (Sumber : Google dan instagram @Tiwul kukus_gm)

Karena penjualannya yang meningkan pesat dan antusisas konsumen yang tinggi membuat Tiwul Kukus menjadi salah satu destinasi kuliner wisatawan saat berlibur ke Daerah Gunung Kidul, karena namanya yang kental sebagai icon makanan khas daerah tersebut. Selain itu, penyajian yang di berikan membuat para konsumen memilih produk Tiwul Kukus sebagai Oleh-Oleh untuk di berikan kepada kerabat di daerah. Tiwul sebagai produk yang identik dengan daerah Gudung Kidul ini menarik masyarakat untuk datang beriwisata ke Daerah Gunung Kidul, Yogyakarta.

Tabel 3, data grafik pendapatan toko oleh-oleh Thiwul Kukus tahun 2020

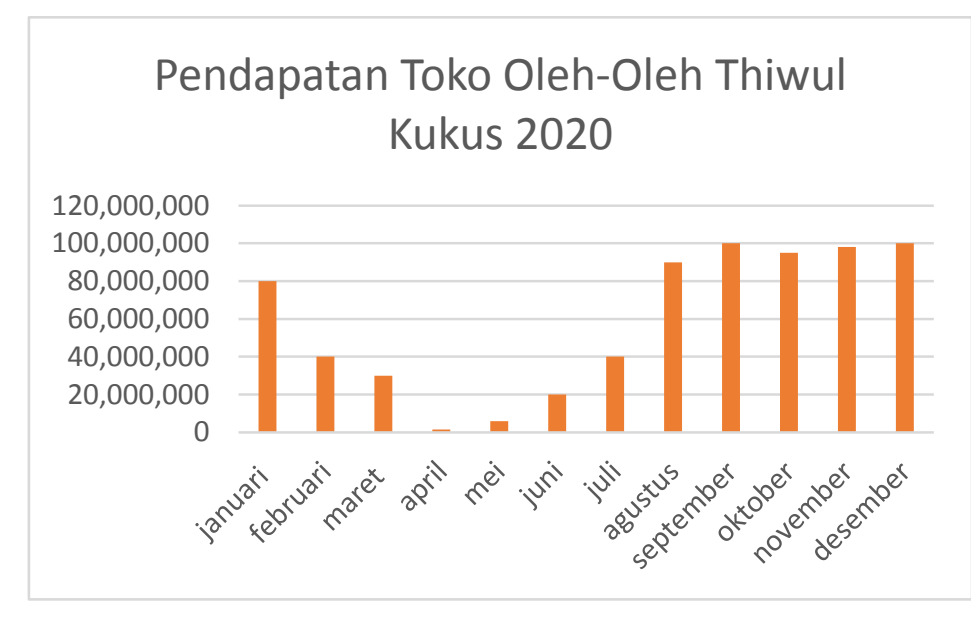

(sumber : catatan pemilik)

Tabel 4, data pendapatan tahunan oleh-oleh Thiwul Kukus

\begin{tabular}{|l|l|l|}
\hline No & Tahun & Debit \\
\hline 1. & 2019 & Rp. 500.000 .000 \\
\hline 2. & 2020 & Rp. 700.000 .000 \\
\hline
\end{tabular}

(sumber : catatan pemilik)

Dengan menjalankan dan melakukan strategi pemasaran yang sesuai dan baik, maka perusahaan dapat memastikan kelancaran untuk pemasaran dan penjualan produk. lebih jelasnya penulis akan menjelaskan dan menguraikan strategi pemasaran apa yang di 
lakukan untuk makanan khas tradisional yang di lakukan oleh Toko Oleh-Oleh Tiwul Kukus:

\section{a. Strategi Produk}

Tedjo sebagai sang pemilik mengatakan bahwa "strategi pemasaran yang saya lakukan adalah menawarkan produk makanan tradisional khas Daerah Gunung Kidul sekaligus melestarikan makanan khas tradisional tersebut sebagai icon daerah dan menjadi daya tarik wisatawan lokal dan internasional".

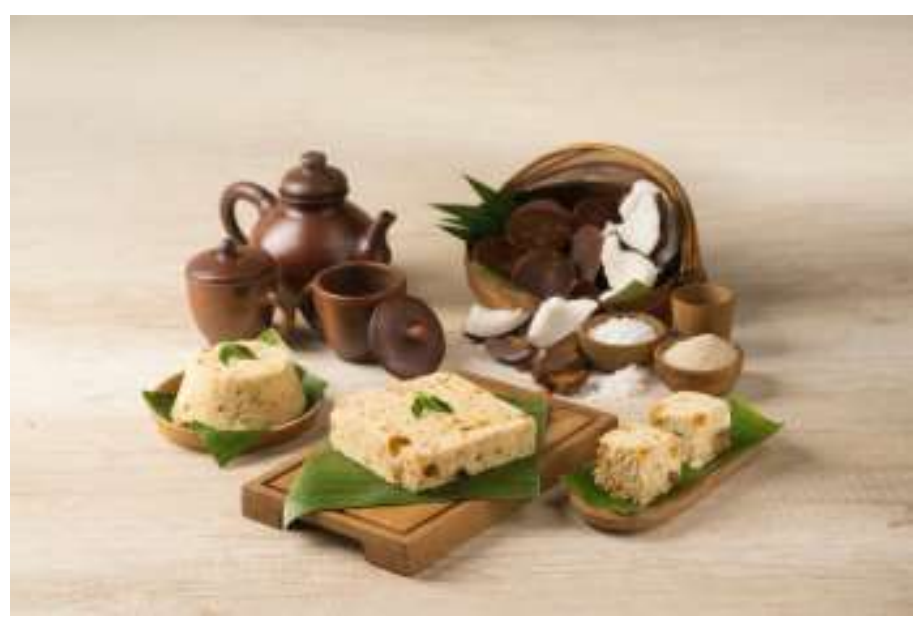

Gambar 3. varian bentuk Thiwul Kukus mengikuti tradisional dan berubah lebih modern (sumber: dokumentasi perusahaan)

Produk adalah hal utama yang penting bagi sebuah perusahaan, karena tanpa adanya sebuah produk di perusahaan maka perusahaan tersebut tidak akan dapat melakukan apapun. Sehingga Tiwul Kukus selalu mengutamakan kualitas produk agar mudah di terima dan di konsumsi disegala kalangan masyarakat. Berinovasi agar semakin menarik namun tidak merubah rasa asli makanan tradisionalnya. Toko Oleh-Oleh Tiwul Kukus berorientasi pada cita rasa sesungguhnya dan kualitas. "Thiwul kukus harus selalu mempertahankan cita rasa thiwul yang sesungguhnya, dengan inovasi yang ada dan menambah kualitas produk namun tidak akan merubah rasa Thiuwl itu sendiri", Ungkap pemilik.

\section{b. Strategi harga}

Menurut Kotler dan Keller (2012) harga merupakan unsur bauran pemasaran yang sifatnya fleksibel dimana setiap saat dapat berubah mengikuti waktu dan lokasi atau daerah dimana penetapan harga di lakukan pada suatu produk akan sangat mempengaruhui keberhasilan penjualan, keuntungan dan pemenuhan target sebuah perusahaan. Penetapan harga dari suatu produk di pengaruhi oleh biaya bahan baku, produksi, biaya tetap dan keuntungan yang di inginkan. Harga sangat mempengaruhi daya beli konsumen terhadap produk, sehingga penentuannya tidak sembarang di lakukan tanpa pedoman satupun, harus ada uraian mengenai biaya yang perlu masuk kedalam perhitungan harga, agar harga yang di jual lebih terjangkau dan operasional perusahaan tetap berjalan.

Tedjo mengatakan "dalam melakukan strategi promosi, menentukan harga jual tentunya tidak semata mata untuk mencari keuntungan, namun berhitung tentang biaya produksi, Jurnal Pemasaran Kompetitif, Vol. 04, No. 3 / Juni 2021 
bahan baku, biaya pengemasan, biaya tetap, dan biaya untuk fasilitas konsumen, agar tetap menjaga kualitas produk namun harga tetap terjangkau dan rasional, sehingga masuk ke segala kalangan masyarakat"

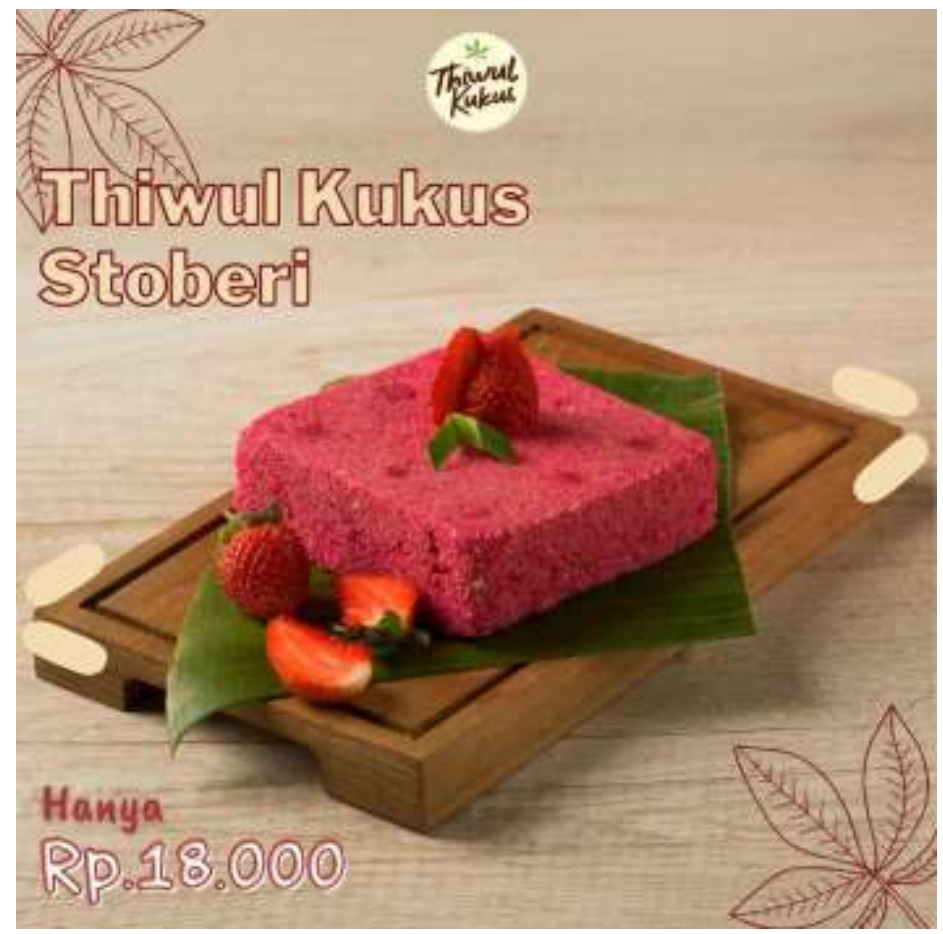

Gambar 4. harga produk Thiwul Kukus

(sumber : Instagram @thiwulkukus_gm)

c. Strategi kebersihan dan kenyamanan

Strategi kebersihan dan kenyamanan yang di maksud adalah kebersihan dalam produksi, mutu produk dan kenyamanan pembeli pada Toko. Kebersihan adalah aspek penting di dalam sebuah produksi makanan dimana kebersihan produk sangat mempengaruhi rasa dan mutu dari produk tersebut.

Tedjo mengatakan "dalam strategi pemasaran Tiwul Kukus sangat memperhatikan kebersihan produksi, toko, dan kenyamanan konsumen. Produksi di lakukan pada dapur khusus dan semua Koki mengunakan pakaian bersih dan lengkap, seperti: celemek, topi, masker, dan sarung tangan. Toko selalu di pel dan di sapu, memberikan tempat duduk agar konsumen dapat nyaman ketika berbelanja di toko kami". 


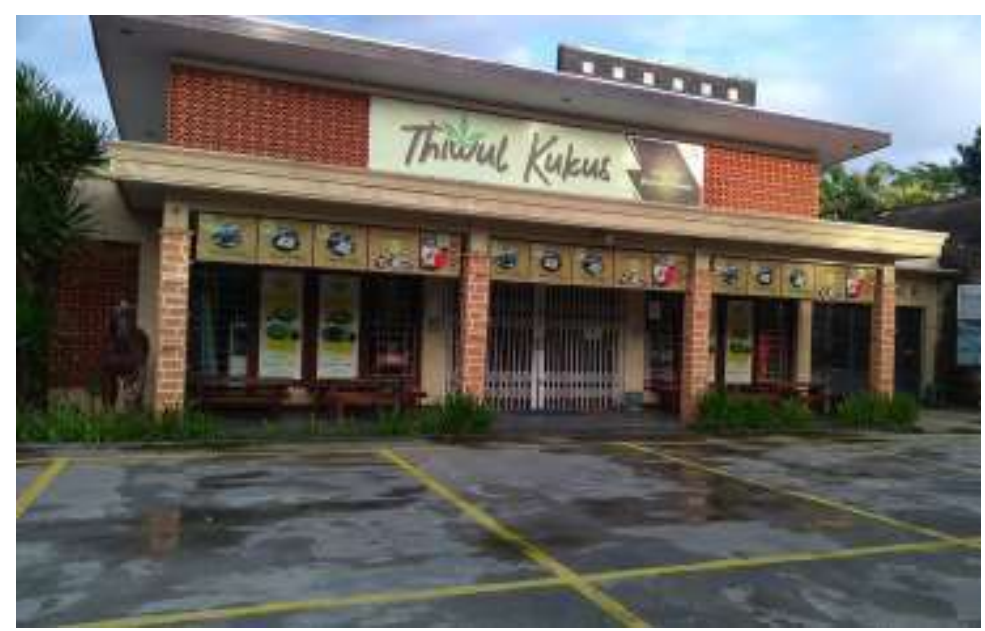

Gambar 5. tampilan depan toko oleh-oleh Thiwul Kukus, Gunung Kidul.

(Sumber: dokumentasi penelitian, 2021)

Kebersihan produk dan toko akan berpengaruh pada keuntungan perusahaan, karena hal tersebut dapat langsung di rasakan oleh konsumen. Sehingga dapat menjadi dampak buruk bila tidak di perhatikan dan sebaliknya, akan berdampak baik bila konsumen merasa puas karena akan menjadi promosi yang di lakukan oleh konsumen itu sendiri dengan cara mulut ke mulut melalui proses pembicaraan sehingga akan melakukan pembelian ulang dan menambah konsumen yang baru karena proses promosi tersebut.

\section{d. Strategi promosi}

Tedjo menjelaskan "dalam melakukan strategi promosi, kami selalu berusaha mengekspose dan mengenalkan produk melalui media apapun, media sosial, media cetak, dan lainnya. Di tambah marketing yang menjemput bis wisatawan ke lokasi destinasi wisata, karena target utama adalah wisatawan yang berlibur dan masyarakat lokal".

Untuk melakukan strategi promosi biasanya di lakukan kegiatan yang bertujuan untuk mengenalkan produk kepada masyarakat agar tertarik untuk membeli, promosi adalah hal paling penting untuk membuat konsumen yakin dan tertarik akan produk yang di jual sehingga target penjualan berhasil di penuhi.

Kegiatan yang dapat di lakukan adalah promosi lewat media sosial, pengenalan produk dengan memberikan tester kepada wisatawan dan masyarakat, membagikan brosur produk, dan menjaga hubungan baik dengan pembeli agar tercipta kenyamanan antara produsen dan konsumen dan kegiatan pemasaran berjalan dengan baik. 


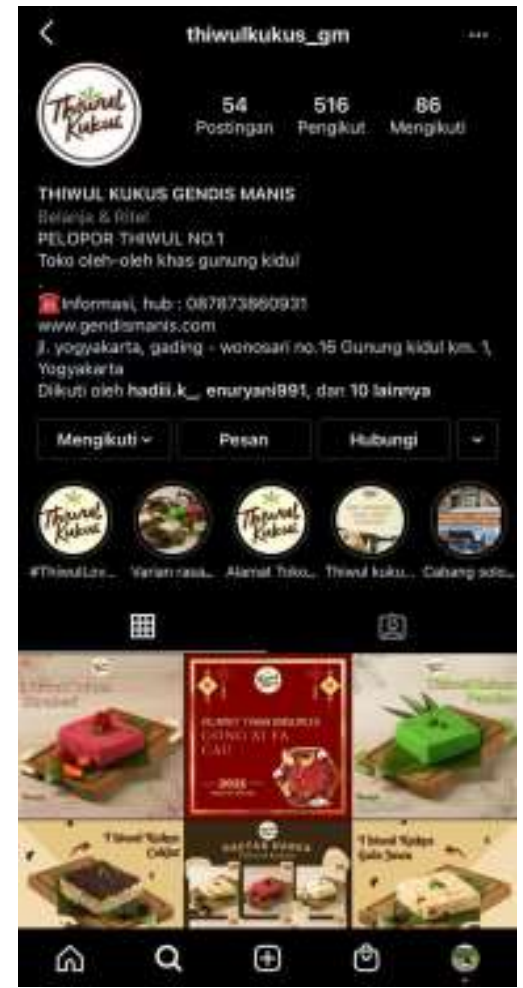

Gambar 6. Tampilan media sosial "Instagram" milik Thiwul Kukus (sumber : Instagram @thiwulkukus_gm)

Berdasarkan strategi pemasaran yang sudah dilakukan oleh Toko Oleh-Oleh Tiwul Kukus, maka perusahaan mendapatkan beberapa hal positif yakni:

a. Dengan adanya produk ini, semakin banyak maskarakat yang teredukasi tentang makanan khas daerah.

b. Meningkatkan daya wisata di daerah karena menarik wisatawan lokal mau pun internasional.

c. Memberikan kesempatan UMKM di sekitar daerah untuk turut menjual produknya di Toko Oleh-Oleh Tiwul Kukus

d. Dengan adanya usaha ini maka akan meningkatkan nilai perekonomian pada masyarakat daerah yang melakukan titip jual produknya ke toko, pemilik usaha, ataupun karyawan yang dipekerjakan di toko ini.

e. Dengan adanya usaha yang memproduksi dan menjual makanan khas daerah Gunung Kidul ini di harapkan dapat melestarikan makanan khas tradisional dan hal tersebut diharapkan akan selalu terjaga keberadaannya sehingga dapat di nikmati oleh masyarakat lainnya di masa yang akan datang.

Tedjo mengatakan "dalam sebulan Toko Oleh-Oleh Tiwul Kukus dapat memperoleh pendapatan sekitar Rp. 25.000.000-Rp.30.000.000 tergantung pada jumlah wisatawan yang berlibur di Daerah Gunung Kidul. Dalam 1 hari di hari libur, Tiwul Kukus bisa di kunjungi 7-12 Bis wisatawan sehingga prospek bisnis Tiwul sangat menguntungkan bila di tekuni dan di perhatikan Strategi Pemasarannya.

dengan adanya usaha makanan tradisional Tiwul Kukus pada akhirnya tidak hanya berdampak kepada pemilik perusahaan melainkan juga berdampak baik pula bagi Jurnal Pemasaran Kompetitif, Vol. 04, No. 3 / Juni 2021 
masyarakat daerah yang turut bermitra dan menjual produknya di toko oleh-oleh Thiwul Kukus, karyawan toko, konsumen, dan masyarakat sekitar bahkan daya tarik wisatawan terhadap daerah Gunung Kidul untuk berwisata. Penerapan strategi pemasaran yang di lakukan toko oleh-oleh Thiwul Kukus dengan baik dapat meningkat penjualan sehingga mampu mendapatkan profit sebesar besarnya dan menjaga eksistensi usaha.

\section{E. KESIMPULAN}

Strategi pemasaran makanan tradisional Tiwul sebagai destinasi wisata kuliner di Daerah Gunung Kidul terdiri dari empat strategi, yaitu strategi produk, strategi harga, strategi kebersihan dan kenyamanan, dan strategi promosi. 1. Strategi produk yang digunakan pada Toko Oleh-Oleh Tiwul Kukus yaitu dengan menyediakan produk makanan tradisional yang ada di Daerah Gunung Kidul dengan kualitas cita rasa yang terjaga. 2. Strategi harga yang digunakan Toko Oleh-Oleh Tiwul Kukus yaitu dengan menerapkan harga yang terjangkau bagi masyarakat pada umumnya. 3. Strategi kebersihan dan kenyamanan yang diterapkan pada Toko Oleh-Oleh Tiwul Kukus yaitu menerapkan kebersihan pada area produksi dan kualitas makanan serta kenyamanan fasilitas toko. Karena dengan adanya kebersihan, pelanggan tidak akan khawatir lagi dalam menikmati produk yang ditawarkan. 4. Strategi promosi yang digunakan pada Toko Oleh-Oleh Tiwul Kukus yaitu dengan cara pemasaran di semua media baik online maupuan offline. Pemasaran online dilakukan dengan memanfaatkan media social sedangkan offline dilakukan dengan penjemputan bis ke lokasi destinasi wisata agar wisatawan tertarik untuk membeli.

Dari penerapan keempat strategi tersebut Toko Oleh-Oleh Tiwul Kukus mampu meningkatkan pendapatan. Jika diterapkan secara konsisten maka diharapkan usaha di bidang kuliner dengan makanan khas ini dapat berkembang lebih luas membawa nama daerah Gunung Kidul dan dapat di kenal oleh seluruh masyarakat lokal maupun manca negara. Dengan adanya hal tersebut dan dengan di terapkannya strategi pemasaran yang baik maka penjualan dan permintaan produk akan meningkat dan perusahaan mendapatkan banyak laba, serta menghasilkan konsumen atau pembeli baru.

Hasil penelitian ini mengkonfirmasi bahwa strategi pemasaran juga relevan dengan usaha skala kecil yakni makanan tradisional Tiwul Kukus. Untuk menegaskan temuan bahwa strategi pemasaran relevan dengan usaha skala kecil maka perlu dilakukan penelitian selanjutnya pada usaha skala kecil lainya, diberbagai bidang selain makanan tradisional.

\section{DAFTAR PUSTAKA}

Acara. (2020). Daerah penghasil singkong terbesar. Diakses 25 maret 2021, dari https://www.acara.co.id/2020/12/daerah-penghasil-singkong-terbesar-di.html

Accurate. (2020) . Pengertian lengkap 7P bauran pemasaran atau marketing mix, dari https://accurate.id/marketing-manajemen/pengertian-lengkap-bauranpemasaran/endayagunaan Aparatur Negara.

Ciputrauceo.net. (2016) . Metode pengumpulan data dalam penelitian, dari http://ciputrauceo.net 
Hartono, Hendry d.k.k. 2012. Pengaruh Strategi Pemasaran Terhadap Peningkatan Penjualan Pada Perusahaan dengan Menetapkan Alumni dan Mahasiswa Universitas Bina Nusantara Sebagai Objek Penelitian. Vol. 3,No. 2:883-889.

Kalurahan Pengkok. (2016). Sejarah kabupaten Gunung Kidul. Diakses 25 maret 2021, dari https://www.pengkok-patuk.desa.id/first/artikel/125-Sejarah--Kabupaten-Gunungkidul

Kemenkeu. (2019) . memahami metode penelitian kuantitatif, dari https://www.djkn.kemenkeu.go.id/artikel/baca/12773/Memahami-Metode-PenelitianKualitatif.html

Kompas.com . (2021). Pendemi ratusan ribu wisatawan kunjungi gunung kidul dalam sepekan. Diakses pada 25 maret 2021, dari https://regional.kompas.com/read/2021/01/01/18160201/pandemi-ratusan-ribuwisatawan-kunjungi-gunung-kidul-dalam-sepekan?page=all

Lesmana, R. (2019). Analisis Strategi Bersaing PT Dwi Perkasa Mobiltama Pamulang untuk Meningkatkan Penjualan. JIMF (Jurnal IImiah Manajemen Forkamma), 3(1).

Lesmana, R., Sunardi, N., Hastono, H., \& Widodo, A. S. (2021). Perceived Quality Membentuk Customer Loyalty via Brand Equity pada Pengguna Smartphone Merek Xiaomi di Tangerang Selatan. Jurnal Pemasaran Kompetitif, 4(2), 157-167.

Mujiburrahmad Mujiburrahmad, Analisis Nilai Tambah Industri Pengolahan Bubuk Kopi UD Ayam Merak di Desa Garot Cut kecamatan Indrajaya Kabupaten Pidie, Mujiburrahmad, Vol. 4 NO. 1, 2018.

Negriku indonesia. (2015) . Thiwul makanan tradisional dari Gunung Kidul, dari http://www.negerikuindonesia.com/2015/06/tiwul-makanan-tradisional-darigunung.html

Nova Sriwanda, 2017. Prospek Usahatani Kakao Kecamatan Bandar Baru Kabupaten Pidie Jaya, Mahasiswa Program Studi Magister Agribisnis Fakultas PertanianUniversitas Syiah Kuala, Sriwanda, Vol 3, No 2,

Nur Hasni Burhanuddin. 2018.Strategi Pemasaran Makanan Khas Tradisional di Kecamatan Wotu, DINAMIS - Journal of Islamic Management and Bussines Vol. 1, No.2 ,

Sunardi, N., \& Lesmana, R. (2020). Konsep Icepower (Wiramadu) sebagai Solusi Wirausaha menuju Desa Sejahtra Mandiri (DMS) pada Masa Pandemi Covid19. JIMF (Jurnal Ilmiah Manajemen Forkamma), 4(1).

Wijaya, Arik Adi, 2013. Analisis Strategi Pemasaran Makanan Khas Tradisional (Studi Kasus Home Industry Rengginang Halimatus Sa'diyah Kalibaru di Kabupaten Banyuwangi, Skripsi: Fakultas Ekonomi Universitas Jember,

Yumanda, Syahreza, 2009. Strategi Pemasaran Keripik Singkong Industri Rumah Tangga Cap Kelinci di Tanjung Morawa Kabupaten Deli Serdang, Skripsi: Departemen Sosial Ekonomi Pertanian Fakultas Pertanian Universitas Sumatera Utara 